\title{
sciendo
}

DOI.10.2478/ANPM-2019-0017

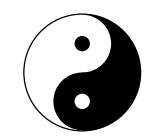

\section{COURT BEADS: MANCHU RANK SYMBOLS IN THE NÁPRSTEK MUSEUM}

\author{
Helena Heroldová ${ }^{1}$
}

\begin{abstract}
Court beads worn with formal dress represented one of the symbols of social standing of the Qing dynasty aristocracy and officialdom. The appearance of court beads and material used for their production were prescribed in the $18^{\text {th }}$ century encyclopaedic work The Illustrated Regulations for Ceremonial Paraphernalia of the Imperial Court. Nowadays, court beads are found in antiquities markets and in museum collections. The Náprstek Museum in Prague also keeps a small collection distinguished from the several tens of pieces of Qing dynasty formal dress, dress accessories, and other signs of social rank, the number of these items are surprisingly few. In order to answer the question about the scarcity of the objects, the origin of the collection has been studied.
\end{abstract}

KEY WORDS: Buddhist rosaries - Court beads - Material Culture Studies - Qing Dynasty - Scholars-officials - Chinese dress - Chinese jewellery

\section{Introduction}

Court beads (chaozhu 朝珠) - long strings of beads made of various materials - were a part of the official dress worn by men and women during the Qing dynasty (16441911) in China. Court beads today frequently appear in antiquities auctions and in museum collections. The Náprstek Museum in Prague keeps a small collection of eight pieces. This study presents the description of the court beads contained in the Náprstek Museum; however, the focus is paid to the history of their collection. Unlike hundreds

1 Contact: Helena Heroldová, National museum - Náprstek Museum of Asian, African and AmericanCultures; e-mail: helena_heroldova@nm.cz. This work was financially supported by Ministry of Cultureof the Czech Republic (DKRVO 2018/32, DKRVO 2019-2023/19.I.a, National Museum, 00023272).

This work is licensed under the Creative Commons Attribution-Noncommercial-No Devivs 3.0 License 
of objects that belonged to the Late Qing Dynasty scholar-officials (e.g., dragon robes, rank badges with embroidered and woven symbols of rank in the hierarchy of the state administration, as well as other various symbols of their social standing like hat buttons and belt buckles, and signs of a one's successful belonging among the intellectual elite such as fans and snuff bottles), court beads are very rare in the Náprstek Museum collection. Even the Buddhist praying strings that can be easily confused with incomplete court beads are more numerous. A large number of objects in the museum collection can be indicative of great interest among the collectors, ease of availability, or general fashionability to collect them. However, the small presence of certain objects in the collection poses the opposite questions. Were those objects unavailable for some reason, were they unable to arouse interest, or were they misunderstood among the collectors? Although, today one cannot longer find out all the answers, with those questions in mind, the study of their ownership helps to illuminate their importance among the museum collection in general.

\section{Court Beads in the Qing Dynasty Cultural History}

Court beads, also called Mandarin necklaces in English, are mainly studied as part of formal and semi-formal ${ }^{2}$ dress during the Qing dynasty (Dickinson and Wrigglesworth, 2000; Garrett, 2007; Haig and Shelton, 2006; Jackson and Hugus, 2005; Wilson, 1986). As such they belonged among the signs of the social rank of the person who wore them. It may have been either a man or a woman, since the official dress was associated with the social position, not with the actual person. Like with other rank indicators such as belts and hats with finials made of colourful stones, the materials played an important role. According to the Qing dynasty dress regulation, certain materials were prescribed while others were prohibited for various ranks of the Imperial family and members of the state administration.

Although the court beads served as important indicators of social position, their origin is based upon the Buddhist ${ }^{3}$ tradition of praying strings. Buddhist rosaries were presumably introduced at the Qing court during the reign of the Emperor Shunzhi 順治 (r. 1644-1661), and they were commonly used there (Dickinson and Wrigglesworth, 2000:158; Kieschnick, 2003: 116). Shunzhi's successor, the Kangxi Emperor 康熙 (r. 16621722), was portrayed later in his life wearing the court robe with the red-coloured beads with green praying strings. ${ }^{4}$

The meaning of Buddhist praying strings shifted from a religious object ${ }^{5}$ to a status symbol, while some of their liturgic function remained (Kieschnick, 2003: 117). As

2 The division into formal, semi-formal, and informal dress is based upon the Qing dynasty dress regulation The Illustrated Regulations for Ceremonial Paraphernalia of the Imperial Court. "Court" clothing included formal dress worn at the Imperial court. The term "official" is used generally for formal and semi-formal styles. The division appears almost in every English-language book about Chinese dress and adorment. The terms depict the social function of the dress, as well as its style, materials, and embelishment. See Heroldová, 2017.

3 For the tradition of rosaries in Christianity and Islam, see Kieschnick, 2003: 118.

4 This famous portrait is kept in the Palace Museum, Beijing, PRC. Online: https://en.dpm.org.cn/ collections/collections/2017-12-28/5525.html. Accessed 29. 6. 2019.

5 See the official portrait of Empress Xiaozhuang 孝莊 (1613-1688), mother of Shunzhi Emperor, painted about 1750 probably by the Jesuit painter Giuseppe Castiglione (1688-1766). In contrast to official posthumous portraits, she is depicted wearing a simple gown, and she is holding the court beads in her hands as if praying. See Wang and Stuart, 2018: 196, 197, pl. 40. 
status symbols worn with formal and semi-formal dress, their appearance was depicted in the essential text dealing with the Qing dynasty dress code, "The Illustrated Regulations for Ceremonial Paraphernalia of the Imperial Court" (Huangchao liqi tushi, 皇朝礼器图式). ${ }^{6}$ This vast work was published in 1766, and the revised and corrected version appeared in 1796. The 1766 edition appeared in eighteen volumes and five thousand pages of text with six thousand illustrations (Garret, 1999: 9) and depicted various rituals and everyday objects used by the Imperial household. Volumes four to seven are devoted to the clothing. This part, entitled “Headdress and clothing” (Guanfu 冠服), appears also in the black-and-white print version used for the purpose of this study. ${ }^{7}$

The Illustrated Regulations represented a model catalogue of dress of the Imperial family, aristocracy and officials. Their social function in the hierarchy of the Qing state was stressed, and dress became the visible representation of their social standing, while the prescribed materials and designs were signs of the dressing code. The dress, as well as headdress and jewellery, were described in text and depicted in pictures.

Court beads of the Emperor (huangdi皇帝) are discussed in Volume Four of The Illustrated Regulations. ${ }^{8}$ The Emperor wore eastern pearls (dong zhu 東珠), blue lapis lazuli (qingjinshi 青金石), red coral (shanhu珊瑚), and blue turquoise (lüsongshi緑松石) strung on the bright yellow (minghuang se明黄色) string. The Crown Prince (huang taizi 皇太子) wore coral, turquoise and lapis lazuli on the bright yellow string (apricotyellow colour, Dickinson and Wrigglesworth, 2000: 158). ${ }^{9}$ Princes (huangzi 皇子) were forbidden to use (bu de yong 不得用) eastern pearls. The string was golden yellow (jinhuang se 金黄色). ${ }^{10}$ Lords (beile貝勒) wore strings in blue colour (shiqing se 石青色). ${ }^{11}$ Blue colour string was the sign of the officials (mingong民公) who were selected through system of Imperial examinations to serve in the administration of the state. During the Qing Dynasty, there were nine civil and nine military ranks. For the everyday administration of the state, the fifth rank was the most common and important for the everyday administration of the state. The highest ranks starting from the first one were reserved for court officials. Only the civil official from the first to the fifth rank and military above the fourth rank (Garrett, 2007: 73; HLT) were entitled to wear court beads. The beads were made of coral, lapis lazuli, turquoise and yellow/red amber (mipo 蜜珀). ${ }^{12}$

Men wore one string of court beads (Jackson and Hugus, 2005: 90), while ladies wore three of them: one around the neck and two diagonally over one's shoulder and under the armpit. The Empress (huanghou皇后) wore one string made of eastern pearls and two of corals on a bright yellow string. ${ }^{13}$ The Imperial Noble Consort (the Emperor's second wife, huang guifei皇貴妃) wore amber and coral beads on a bright

\footnotetext{
6 For the purpose of this study, the electronic version of the black-and-white print with pictures, with no other publishing data, was downloaded from the collection of the Bibliothèque nationale de France, www http:/ / gallica.bnf.fr.

7 For the history of The Illustrated Regulations, see Medley, 1982.

8 The abbreviation of the title Huangchao liqi tushi, HLT, is used further in the text. HLT, Volume 4, Guanfu 冠服 1, Huangdi 皇帝, p. 13.

9 HLT, Volume 4, Guanfu 冠服 1, Huang taizi皇太子, p. 36.

${ }^{10}$ HLT, Volume 4, Guanfu 冠服 1, Huangzi皇子, p. 49.

11 HLT, Volume 4, Guanfu 冠服 1, Beile貝勒, p.?.

12 HLT, Volume 5, Guanfu 冠服 2, Mingong民公, p. 8.

${ }^{13}$ HLT, Volume 6, Guanfu 冠服 3, Huanghou 皇后, p. 24.
} 
yellow string. ${ }^{14}$ Noble Consorts (guifei貴妃) wore the same court beads as the Imperial Noble Consort, but on a golden yellow string. ${ }^{15}$ Concubines (pin嬪) wore amber and coral, the same as Noble Consorts. ${ }^{16}$ The Prince's Consorts (huangzi fujin 皇子福晉) used amber and coral on a golden yellow string. ${ }^{17}$ The Lords' wives (beile furen 貝勒夫人) wore the same court beads as the Prince's Consorts, but strung on a blue string. ${ }^{18}$ Wives of the officials (mingong furen民公夫人) had coral, lapis lazuli and amber on a blue string. ${ }^{19}$

As described in The Illustrated Regulations, eastern pearls, coral, lapis lazuli, amber and turquoise were prescribed for the Imperial family and the highest officials. However, other materials were also used, such as enamelled metal (Wilson, 1986: 29), wood, seeds, and glass. Glass was known to Chinese since the first millennium BC, however it was not used commonly (Needham, 2004: 101). During the Qing dynasty, various types of glass, clear, translucent, opaque, and coloured were used to produce high quality items - vases, bowls, boxes and snuff bottles (Warren, 1977). Court beads from the Náprstek Museum were also made either from opaque coloured glass, probably as an imitation of more valuable materials such as jade (see Nos. 2,3,4,5,6,7), or from clear coloured material that served for its own aesthetic qualities (see Nos. 1). Wooden beads and carved and uncarved seeds are also common with court beads in the Náprstek Museum collection (Nos. 1, 2, 3, 5, 6). ${ }^{20}$ Seeds probably came from trees or shrubs of the genus prunus which includes apricots, peaches, and plums-those flowers or fruits and pits that convey important symbolism in Chinese culture. Peaches especially form a typical visual motif in textile and applied arts as symbols of longevity and protection against evil spirits. Carved seeds with tiny holes and uneven lines can probably imitate rudraksha seeds with typical vertical lines that come from the tree Elaeocarpus ganitrus, which is common in south and southeast Asia and partly in the Himalayas and China. The rosaries made of rudraksha seeds were used in India and China. The rosary made of Elaeocarpus appeared in the Chinese novel Dream of the Red Chamber (Hongloumeng) written by Cao Xueqin in the middle of the 18th century (Kieschnick, 2003: 116).

Court beads have a distinctive looks (Plate 1). The drawings of the court beads are found in the The Illustrated Regulations along with the explanation of what material was used. The beads themselves counted for one hundred and eight divided into groups of twenty seven. ${ }^{21}$ The numbers 108 and 27 had symbolic meaning based upon Buddhist and Hinduist thought as well as represented Chinese belief. Twenty seven consisted on "three times nine"; the number nine represented the "perfect number" because it contained three times three, "the most basic unit of three being heaven, earth, and man" (Welch, 2008: 225, 257). The large beads that divided the groups were called Buddha

${ }^{14}$ HLT, Volume 6, Guanfu 冠服 3, Huang guifei皇貴妃, p. 43.

${ }^{15}$ HLT, Volume 6, Guanfu 冠服 3, Guifei貴妃, p. 65.

${ }^{16}$ HLT, Volume 6, Guanfu 冠服 3, Pin嬪, p. 91.

${ }^{17}$ HLT, Volume 6, Guanfu 冠服 3, Huangzi fujin皇子福晉, p.?

${ }^{18}$ HLT, Volume 6, Guanfu 冠服 3, Beile furen貝勒夫人, p. 143.

${ }^{19}$ HLT, Volume 7, Guanfu 冠服 4, Mingong furen民公夫人, p. 9.

${ }^{20}$ The author expresses her thanks for information about the seeds in court beads to Ms Radka Rosenbaumová (radka_rosenbaumova@nm.cz), Department of Botany, National Museum, Prague.

${ }^{21}$ The complete strings of court beads from the Náprstek Museum show a different number of beads, from 88 to 108 . 
heads (fotou 佛頭, Kieschnick, 2003: 135; Haig and Shelton, 2006: 203; Dickinson and Wrigglesworth, 2000: 158). The Manchus during the Qing dynasty added two new elements to the original Buddhist praying strings (Jackson and Hugus, 2005: 90). A long counterweight tape with a plaque called back cloud (beiyun 背雲) hung on the back of the dress (Kieschnick, 2003: 135). The flat tape was made of silk. The plaques were produced from various materials including metal, cloisonné, glass and semi-precious stones. From the shoulder near to a man's heart hung two strings of counting beads (jinian 記念), while one string was on the other shoulder. The ladies wore the court beads on the other side (Welch, 2008: 257). The counting strings threaded ten beads divided into five. Each string ended with a teardrop pendant made of glass or stone embedded in a metal rim.

\section{The Náprstek Museum Collection}

There are only a few court beads in the Náprstek Museum collection. However although it is a small collection, it demonstrates various material and workmanship, as well as later re-designing of the objects. Glass became a predominant material. Opaque glass in shades of white and green imitated jade, and glass beads in pink and red colour were used instead of semi-precious stones. ${ }^{22}$ However, translucent light blue glass (No. 1) stands for itself and shows its aesthetic qualities. Other materials included carved and smooth seeds, turquoise and resin, probably as imitation of amber. Moreover, the metal rims around the back tape plaques ${ }^{23}$ and teardrop pendants show the frequent use of kingfisher feathers (Alcedo atthis). The kingfisher feathers are almost gone now; however there are visible remains of them in the filigree decoration. Kingfisher feathers have been used in Chinese jewellery for centuries. Its lustrous beauty was depicted in ancient Chinese poetry. It symbolised royalty and wealth, but its glamour carried also a possibility of the tragic fate, because the bird with glittering feathers was constantly in danger of being caught (Kroll, 1984: 242-3, 246). The combination of metals of golden colour and blue-green kingfisher feathers was popular, and jewellery pieces decorated with kingfisher feather became a common export article to Europe in the 19th century.

Although the court beads represent an interesting part of Qing dynasty social and cultural history, they are surprisingly rare in the Náprstek Museum collection, as opposed to hundreds of textiles and dress accessories from the same period. Although the court beads came from only a few collectors, they are from those who can now be labelled as experts in certain fields of collecting and arts. This is probably the reason why they focused on the acquisition of court beads that otherwise stood beyond the fashionable collecting of clothing and embroideries.

The court beads were acquired in the 1920s and 1930s. Two sets appeared in the Museum later, but they were part of pre-Second World War collections. No one among the collectors visited China; however all of them were connected to art in general, to China and Asia. Růžena Trnožková (died 1936, other information about her life is not available) was a wife of a trade superintendent and gathered a large collection of fine clothing from China and Japan. (Nos. 1,4). František Adolf Borovský (1852-1933) was

${ }^{22}$ The author thanks to Mr. Lukáš Zahradníček, the curator of the Collection of cut gemstones, Národní Museum (lukas_zahradnicek@nm.cz).

${ }^{23}$ The dimensions of the court beads are more or less the same. The back tape plaques lenght is about $5 \mathrm{~cm}$. Large fotou beads measure approximately $2.5 \mathrm{~cm}$. 
an art historian who collaborated with the museum established by Vojtěch Náprstek (1826-1894) since the 1880s and between 1918-1925 became the member of the museum board. Between 1911-1914 he served as the director of the Museum of Applied Arts in Prague (No. 2). ${ }^{24}$ Joe Hloucha (1881-1957) was a fashionable author of sentimental novels set in Japan, and a collector of Asian as well as European medieval and folk art (No. 3). He visited Japan twice, in 1906 and 1926 (Kraemerová and Šejbl, 2007). One set of the re-designed court beads belonged to the collection of Albert Sachse (1851-1921), a businessman who established a glass jewellery export company Assam \& Sachse and focused on Asian and African markets before the First World War (No. 7). The other one came from a private collection acquired after the Second World War (No. 8). This set was probably remade especially to suit the European taste for exotic Oriental jewellery. The subdued beauty of resin and jade was combined with shiny metal pieces and colourful glass beads.

As opposed to lavish pieces of Chinese textiles that easily found their way into the private collections and later to the Náprstek Museum, court beads were collected only by those who appreciated craftsmanship and unobtrusive beauty, whether or not they were aware of their function of an important symbol of social position.

\section{Plates}

\section{Plate 1.}

The court beads, according to The Illustrated Regulations. ${ }^{25}$ The beads are divided into groups of twenty seven by four large beads. Three counting strings are on the right and left sides. The long counterweigh tape was worn on the back.

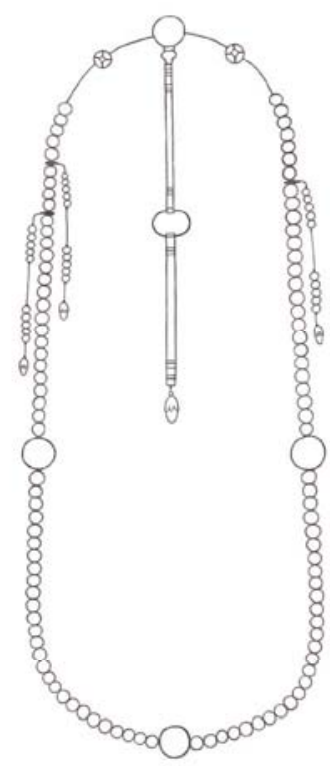

${ }^{24}$ For his short biography, see the project Provenio. /http://opac.nm.cz:8080/authorities/48658, Accessed 28. 6. 2019.

${ }^{25}$ A digital drawing by the author. 


\section{Plate 2}

Inv. No. 19430

Ancestor portrait

Colours on silk

Length $300 \mathrm{~cm}$ width 115

After 1850

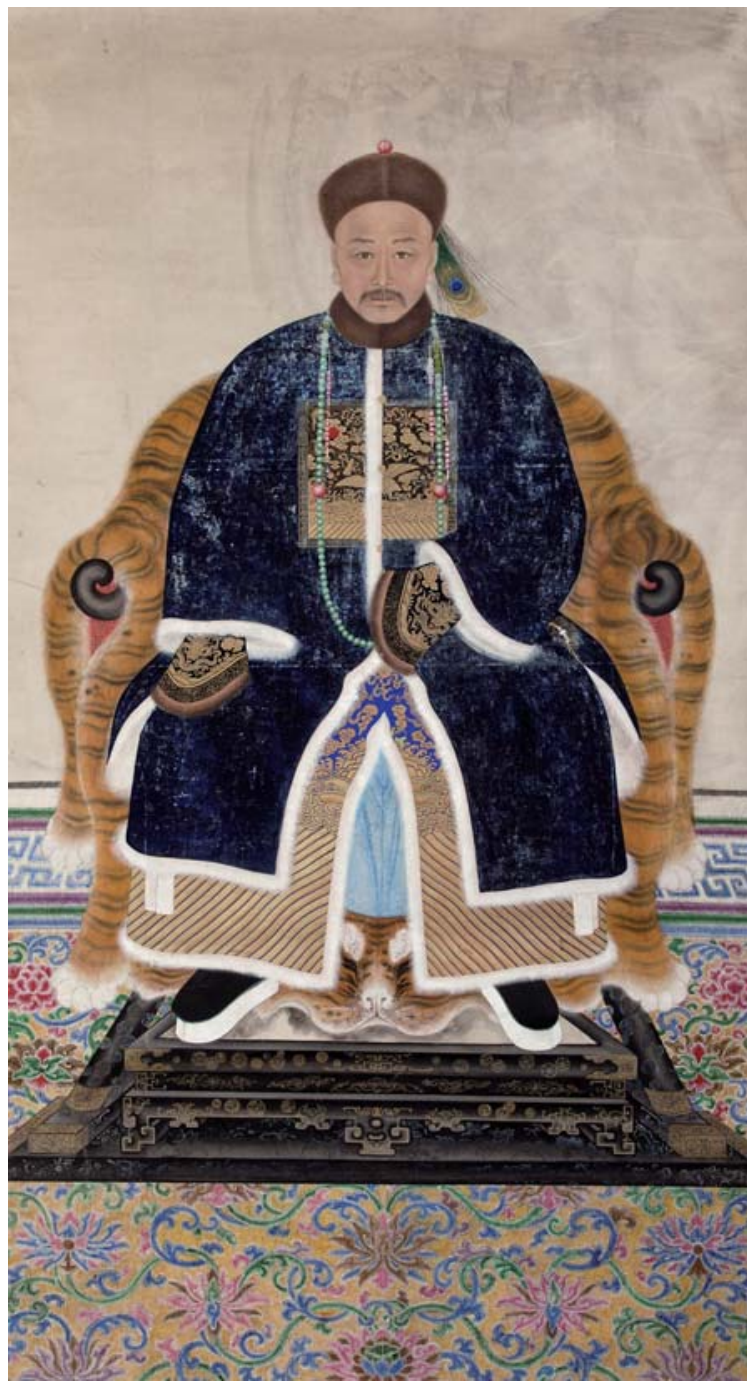

This ancestor portrait depicts a man in a blue and gold dragon robe trimmed with fur and a dark blue surcoat with the rank badge embroidered with golden thread. It shows a crane, a symbol of the highest of civil ranks. The man is wearing a winter hat with a red stone finial and a peacock feather - an award for merit. The court beads are bluegreen with red Buddha heads. The blue stones can be either lapis lazuli or turquoise, both used by the highest official rank (Heroldová, 2017: 43, fig. 20). 


\section{Catalogue ${ }^{26}$}

\section{No. 1}

Inv. No. 30955

Acquisition: Růžena Trnožková, 1937

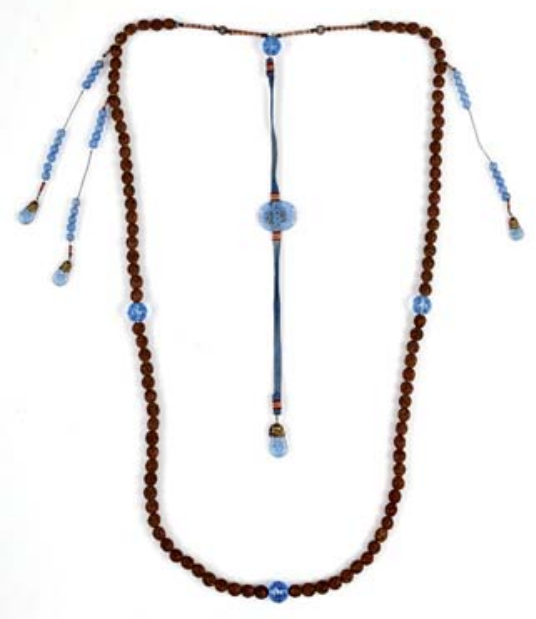

Court beads (100 beads) made from an imitation of rudraksha seeds with four fotou beads made of blue glass. The counting strings are also made of blue glass, the back tape pendant is made of blue glass with carved with endless knot design and tiny holes. A drop-like pendant bears a stylised shou 壽character (Longevity) on a metal frame.

\section{No. 2}

Inv. No. 30958

Acquisition: František Adolf Borovský, 1927

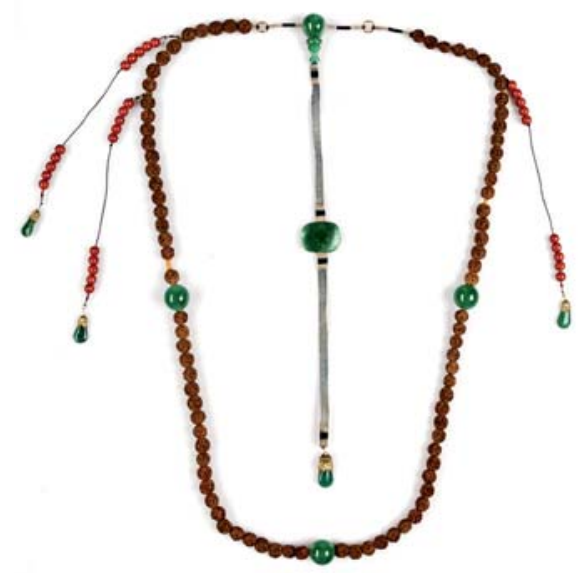

26 The Catalogue is arranged according to the condition of the objects. The complete court beads are listed first, then the incomplete beads are given, and the last object represents the re-made string of court beads. 
Court beads ( 88 beads) made from an imitation of rudraksha seed with four fotou beads made of green glass. The counting strings made of red seeds, with the back tape with flat green jade (?) pendant.

No. 3

Inv. No. 30956

Acquisition: Joe Hloucha Collection, 1943

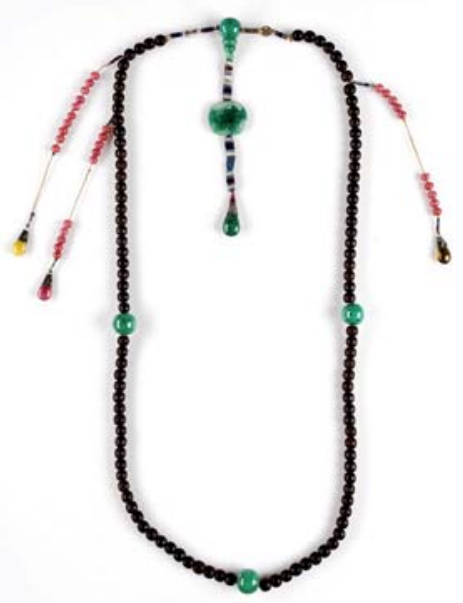

Court beads of wooden beads, green glass fotou beads and counting strings made of pink glass with drop-like pendants in yellow, red and brown glass. The short back tape plaque made of green glass.

No. 4

Inv. No. 30954

Acquisition: Růžena Trnožková, 1937

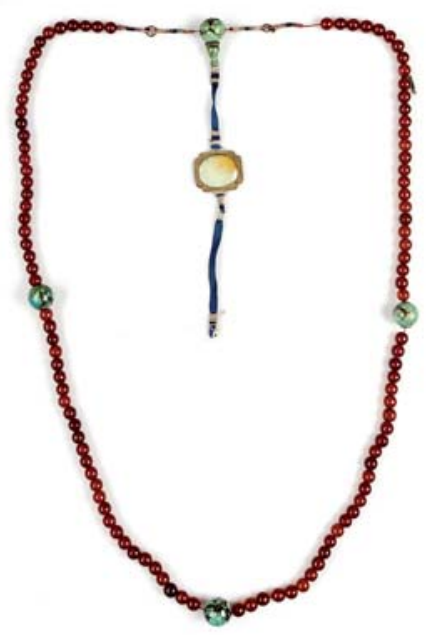


Court beads made of resin beads, with four turquoise beads. A back tape pendant made of yellow colour metal with filigree embellishment and a flat oval yellow glass pendant (the drop-like pendant is missing). Counting strings are missing.

\section{No. 5}

Inv. No. 34536

Acquisition: Joe Houcha

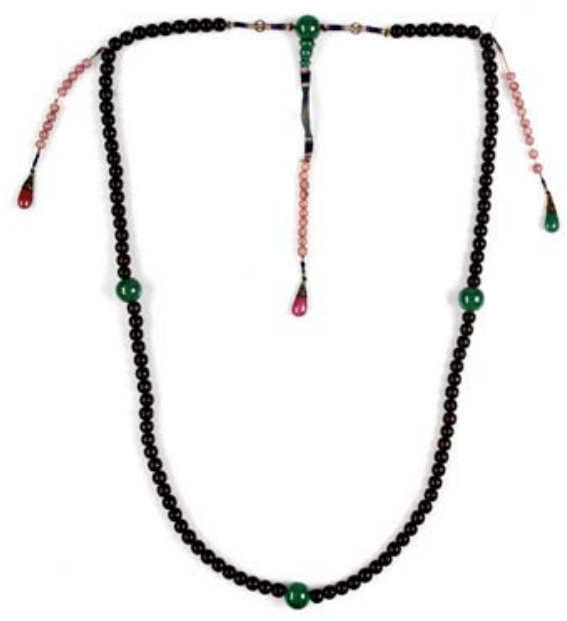

Court beads made of wooden beads, with two counting strings of pink glass pearls. A back tape pendant missing, pink beads added.

No. 6

Inv. No. A/4533

Court beads (91 beads) made of dark brown-black seeds, with green glass fotou beads. The string is broken and tied in several places. The counting strings are missing. A back pendant with a flat metal pendant with a yellow flat glass shows remains of kingfisher feathers.

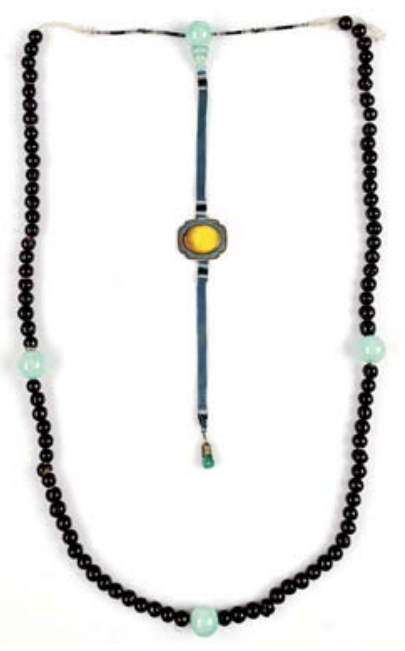


No. 7

Inv. No. 31537

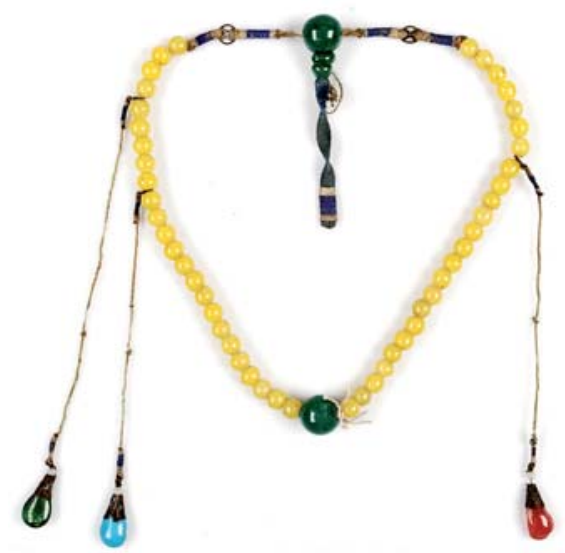

Acquisition: Albert Sachse (1851-1921), 1927

The short court beads are made of yellow glass beads with only two green glass fotou beads. Beads on the counting strings and the back tape pendant are missing.

No. 8

Inv. No. 4744

Acquisition: private collection, Teplice (North Bohemia), 1947

Court beads made of resin beads, a back tape with the jade pendant with an unfinished dragon motif carving. Original components and beads are missing. Metal and glass beads added. Re-designed.

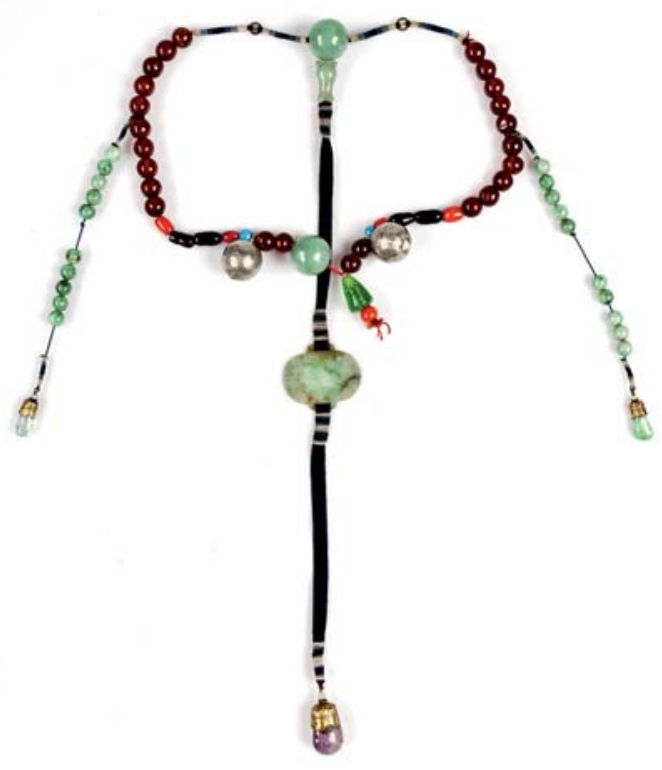




\section{Literature:}

Dickinson, Gary - Wrigglesworth, Linda

2000 Imperial wardrobe. Rev. ed. Berkeley, Calif.: Ten Speed Press.

Garrett, Valerie

2007 Chinese Dress: from the Qing Dynasty to the Present. Tuttle.

\section{Haig, Paul - Shelton, Marla}

2006 Threads of Gold: Chinese Textiles, Ming to Ching. Schiffer Pub.

\section{Heroldová, Helena}

2017 Between Cultures: Manchu and Han Dress of the Late Qing Dynasty in the Náprstek Museum Collection. Praha: Národní museum.

Jackson, Beverley - Hugus, David

2005 Ladder to the Clouds: Intrigue and Tradition in Chinese Rank. Ten Speed Press.

\section{Kieschnick, John}

2003 The Impact of Buddhism on Chinese Material Culture. University Presses of California, Columbia and Princeton

Kraemerová, Alice - Šejbl, Jan

2007 Japonsko, má láska: český cestovatel a sběratel Joe Hloucha. Prague: Národní muzeum.

Kroll, Paul W.

1984 "The Image of the Halcyon Kingfisher in Medieval Chinese Poetry", in: Journal of the American Oriental Society 104/2, pp. 237-251.

\section{Medley, Margaret}

1982 The Illustrated Regulations for Ceremonial Paraphernalia of the Ch'ing Dynasty. London: Han-shan Tang.

\section{Needham, Joseph}

1962 Science and Civilisation in China. Vol. IV., part 1: Physics and physical Technology. Cambridge: Cambridge University Press, 2004 (reprint).

Wang, Daisy Yiyou - Stuart Jan (eds.)

2018 Empresses of China's Forbidden City, 1644-1912. Peabody Essex Museum,

\section{Warren, Phelps}

1977 “Later Chinese Glass 1650-1900”, in: Journal of Glass Studies, 19, pp. 84-126.

\section{Welch, Bjaaland, Patricia}

2008 Chinese Art. A Guide to Motifs and Visual Imagery. Tuttle Publishing.

Wilson, Verity

1986 Chinese Dress. Bamboo Publishing LTD with the Victoria and Albert Museum.

\section{Internet Sources:}

"The Illustrated Regulations for Ceremonial Paraphernalia of the Imperial Court" (Huangchao liqi tushi, 皇朝礼器图式), np., nd. Online: www http://gallica.bnf.fr.

Provenio. Online: http:/ /opac.nm.cz:8080/authorities/48658, Accessed 28. 6. 2019.

Portrait of the Kangxi Emperor in Court Robe. Online: https: / / en.dpm.org.cn/collections / collections /2017-12-28/5525.html, Accessed 29. 6. 2019. 